TITLE:

\title{
Phylogenetic diversity of the picocyanobacterial community from a novel winter bloom in Lake Biwa
}

$\operatorname{AUTHOR}(\mathrm{S}):$

Cai, Ji; Hodoki, Yoshikuni; Nakano, Shin-ichi

CITATION:

Cai, Ji ... [et al]. Phylogenetic diversity of the picocyanobacterial

community from a novel winter bloom in Lake Biwa. Limnology 2021, 22(2): 161-167

\section{ISSUE DATE:}

2021-04

URL:

http://hdl.handle.net/2433/267534

\section{RIGHT:}

This version of the article has been accepted for publication, after peer review (when applicable) and is subject to Springer Nature's AM terms of use, but is not the Version of Record and does not reflect post-acceptance

improvements, or any corrections. The Version of Record is available online at: http://dx.doi.org/10.1007/s10201-02000649-5; The full-text file will be made open to the public on 04 February 2022 in accordance with publisher's 'Terms and Conditions for Self-Archiving'.; This is not the published version. Please cite only the published version. この論文は 出版社版でありません。引用の際には出版社版をご確認ご利用ください。 
1 Phylogenetic diversity of the picocyanobacterial community from a

2 novel winter bloom in Lake Biwa

$3 \mathrm{Ji} \mathrm{Cai}^{1}$, Yoshikuni Hodoki ${ }^{2}$, Shin-ichi Nakano ${ }^{1 *}$

$4 \quad{ }^{1}$ Center for Ecological Research, Kyoto University, Otsu 520-2113, Japan

$5{ }^{2}$ Ibraki Kasumigaura Environmental Science Center, 1853 Okijuku-machi, Tsuchiura,

6 Ibaraki, 300-0023, Japan

7 *Mailing address: Center for Ecological Research, Kyoto University, Hirano-cho 2

8 chome, 509-3, Otsu, Shiga 520-2113, Japan.

9 Phone and Fax: +81-77-549-8239, +81-77-549-8201

10 E-mail: nakano@ecology.kyoto-u.ac.jp 


\section{Abstract}

12 In Lake Biwa, picocyanobacteria blooms usually occur during the summer-autumn

13 thermal stratification period. Intriguingly, a novel bloom was detected in winter 2015-

14 2016, in which picocyanobacterial cell density increased by one order of magnitude

15 despite lower water temperature, suggesting the possibility that "cold-water-preference"

16 species dominate in the picocyanobacterial community. In the present study, we

17 investigated the phylogenetic diversity of picocyanobacteria in Lake Biwa by analyzing

18 the $16 \mathrm{~S}$ rRNA gene. We found that the picocyanobacterial community were highly

19 diverse in Lake Biwa, with eight Synechococcus-related operational taxonomic units

20 (OTUs) detected in different seasons. These OTUs fell into distinct phylogenetic groups,

21 and the majority were closely related to clusters reported previously. Notably, OTU04,

22 detected during the winter bloom, was highly affiliated with sequences found in a

23 variety of lakes, such as Tibetan lakes and Lake Superior, where the water bodies

24 generally have a low trophic state and temperature, and different concentrations of total

25 dissolved solids. Thus, we inferred that the group containing OTU04 may be a

26 psychrotolerant lineage that is widely distributed in oligotrophic water systems with

27 low-intermediate salinity.

28 Keywords: 16S rRNA; picocyanobacteria; phylogenetic diversity; psychrotolerant

\section{Introduction}

30 Picocyanobacteria, which are generally unicellular cyanobacteria smaller than $2 \mu \mathrm{m}$, are

31 ubiquitous photosynthetic microorganisms in aquatic ecosystems (Stockner and Antia 
32 1986; Stockner 1988). Despite their small size, picocyanobacteria contribute

33 significantly to primary production and form the basis of food webs in various types of

34 lakes and oceans (Stockner 1991; Weisse 1993; Callieri et al. 2013). In freshwaters,

35 they are mainly represented by the genera Synechococcus and Cyanobium, which often cannot be distinguished clearly (Callieri 2008).

Seasonal variation in picocyanobacterial abundance in lake ecosystems has received considerable attention during the last few decades. It has been widely acknowledged that temperature is an important driver of picocyanobacterial growth and abundance (Beardall and Raven 2004; Vörös et al. 2009; Jodłowska and Śliwińska 2014; Śliwińska-Wilczewska et al. 2018), and picocyanobacteria generally reach maximum cell densities $\left(10^{5}-10^{6}\right.$ cells $\left.\mathrm{mL}^{-1}\right)$ during summer-autumn thermal stratification in temperate lakes (Stockner et al. 2000; Callieri et al. 2013). Previous studies in Lake Biwa, the largest freshwater lake in Japan, have also reported a similar pattern, i.e., that picocyanobacteria form significant blooms in the epilimnion during summer and early autumn and decline in other seasons (Nagata 1986; Maeda et al. 1992; Nakano et al. 1996; Wakabayashi and Ichise 2004). Intriguingly, we found an increase in picocyanobacterial cell densities in Lake

49 Biwa during winter 2015-2016 despite decreased water temperature (Cai et al. 2020). It

50 is likely that psychrotolerant or psychrophilic species dominated the community during

51 that period. Psychrotolerant Synechococcus have been frequently found in winter oceans

52 (Choi et al. 2013) and polar seas (Tang and Vincent 1999), and some can maintain slow

53 but sufficient growth even at very low temperatures $\left(-1.8^{\circ} \mathrm{C}\right.$ to $4^{\circ} \mathrm{C}$ in Cottrell and

54 Kirchman 2009; nearly $4^{\circ} \mathrm{C}$ in $\mathrm{Xu}$ et al. 2015). In addition, psychrophilic eukaryotic 
55 picophytoplankton that achieve optimal growth rates at $6-8^{\circ} \mathrm{C}$ have also been reported

56 in polar oceans (Lovejoy et al. 2007). However, unlike those in marine systems,

57 freshwater picocyanobacterial lineages that adapt to low temperature conditions remain

58 largely unexplored.

59 In the present study, we investigated the phylogenetic diversity of the

60 picocyanobacteria community in Lake Biwa by analyzing the 16S rRNA gene. We

61 collected water samples in different seasons and determined the $16 \mathrm{~S}$ rRNA sequences

62 by clone-library analyses. By comparing the community structure between summer and

63 winter, we inferred whether the picocyanobacteria that proliferated during the winter

64 were "cold-water-preference" species.

\section{Methods}

\section{Sampling and DNA isolation}

67 Sample collection was conducted biweekly at a pelagic site (Ie-1) in the north basin of

68 Lake Biwa from July 2015 to June 2017 (Cai et al. 2020). Unfiltered water samples were collected from the epilimnion $(5 \mathrm{~m})$. Cell densities of picocyanobacteria were determined by visualizing the autofluorescence under green excitation $(530-550 \mathrm{~nm})$

71 with an epifluorescence microscope (Cai et al. 2020). For DNA extraction, four water 72 samples were collected in August 2015 (2015sum), March 2016 (2015win), July 2016

73 (2016sum), and March 2017 (2016win). For each sample, 0.5 to $1 \mathrm{~L}$ of water was

74 filtered through a $0.2-\mu \mathrm{m}$-pore-size polycarbonate membrane filter (Advantec

75 K020A047A; Toyo Roshi Kaisha, Japan). DNA was extracted from seston on the filter 76 using the PowerSoil DNA Isolation kit (MOBIO, USA) according to the manufacturer's 
77 instructions. Extracted DNA was eluted in TE buffer and stored at $-20^{\circ} \mathrm{C}$ until

78 downstream application.

PCR amplification, cloning, and sequencing

80 Partial 16S rRNA gene of Synechococcus was amplified using the primer set CYA359F (5'-GGG GAA TYT TCC GCA ATG GG, Nübel et al. 1997) and 1499R (5'-CAC

CTT CCG GTA CGG CTA C). PCRs were conducted in a $150-\mu \mathrm{L}$ reaction mixture with the following final reactant concentrations: $1 \times$ PCR buffer, $0.2 \mathrm{mM}$ of each $\mathrm{dNTP}$, $1.5 \mathrm{mM} \mathrm{MgSO}_{4}, 0.3 \mu \mathrm{M}$ of each primer, ca. $600 \mathrm{ng}$ of template DNA, and $1 \mathrm{U}$ of KODPlus-Neo (Toyobo, Japan) polymerase. The PCR conditions were as follows: initial activation of the KOD-Plus-Neo polymerase for 2 min at $94^{\circ} \mathrm{C}$, followed by 35 cycles of $10 \mathrm{~s}$ denaturation at $98^{\circ} \mathrm{C}$, annealing for $30 \mathrm{~s}$ at $60^{\circ} \mathrm{C}$, and extension for $30 \mathrm{~s}$ at $68^{\circ} \mathrm{C}$, and a final extension at $68^{\circ} \mathrm{C}$ for $7 \mathrm{~min}$. The PCR products were purified using a

89 NucleoSpin Tissue kit (Macherey-Nagel, Germany), and cloned using a TArget Clone kit (Toyobo) and Competent High DH5 $\alpha$ (Toyobo) following the manufacturer's

91 instructions. Approximately 40 positive colonies containing PCR products were randomly

93 selected from each sample. The inserted DNA was re-amplified with the T7 and U19

94 primers, and the length of the PCR products was verified by agarose gel electrophoresis.

95 Only PCR products containing the target sequence were sequenced using a BigDye

96 Terminator v3.1 Cycle Sequencing Kit (Applied Biosystems, USA) and a 3130 genetic

97 analyzer (Applied Biosystems). 


\section{Phylogenetic analysis}

99 DNA sequences (V3-V8 region) amplified with the primer set for cyanobacteria were

100 checked against the GenBank database using BLAST (Altschul et al. 1997). Chimeras

101 were identified using vsearch (v.2.6.2; Rognes et al. 2016) and excluded from further

102 analyses. Only sequences related to Synechococcus were grouped together into an

103 operational taxonomic unit (OTU) if their similarity was greater than $99 \%$, considering

104 the high conservation of the 16S rRNA gene (Edgar 2018). Reference sequences of

105 currently known picocyanobacterial clusters and the closest relative of each OTU were

106 downloaded from the GenBank database. In addition, sequences of the V3-V4 region

107 that were highly similar to the OTUs detected in winter were obtained to evaluate the

108 geographical distribution of winter picocyanobacteria. The sequence data were aligned

109 using the MUSCLE algorithm, as implemented in MEGA X (Kumar et al. 2018).

110 Maximum-likelihood trees were constructed using FastTree (Price et al. 2010) and then

111 edited with the "ggtree" package (Yu et al. 2017) in R software (v.3.4.3; R

112 Development Core Team, 2018). The 16S rRNA gene sequences obtained in the present

113 study were deposited in GenBank with accession numbers MT772216 to MT772235.

\section{Results}

115 In Lake Biwa, picocyanobacteria formed significant blooms (up to $4.5 \times 10^{5}$ cells $\mathrm{mL}^{-1}$ )

116 in the epilimnion during June and October (i.e., the thermal stratification period) in both

1172015 and 2016 (Fig. 1). Notably, an increase in picocyanobacterial abundance was also

118 observed during December 2015 and March 2016. Cell densities of picocyanobacteria

119 increased from $3.9 \times 10^{3}$ to $3.4 \times 10^{4}$ cells $\mathrm{mL}^{-1}$, while the water temperature decreased 
120 from 17 to $8^{\circ} \mathrm{C}$. Afterwards, the density decreased to $7.5 \times 10^{3}$ cells $\mathrm{mL}^{-1}$ when the

121 temperature rose to $11^{\circ} \mathrm{C}$ in April 2016, thus forming a winter bloom. During this

122 period, a negative Spearman's rank correlation $\left(r_{s}=-0.915, p<0.001\right)$ was found

123 between picocyanobacterial abundance and water temperature. However, no bloom was

124 observed in winter 2016-2017. After the summer bloom in 2016, picocyanobacterial

125 abundance decreased gradually to $1.5 \times 10^{2}$ cells $\mathrm{mL}^{-1}$ along with temperature, and did

126 not increase until the temperature increased in March 2017.

127 A total number of 20 sequences putatively derived from Synechococcus were

128 detected among all samples, except for 2016win. These sequences were clustered into

129 eight OTUs (01-08) based on 99\% similarity and fell into distinct phylogenetic groups

130 (Fig. 2). OTU01 was detected in summer 2015 and 2016 and was closely affiliated with

131 Cyanobium JJ9-A3. OTU02 and OTU03, both of which were detected in summer 2015,

132 were closely related to the Lake Biwa cluster (Ernst et al. 2003) and Cyanobium

133 Suigetsu-CG4 (group IV in Ohki et al. 2012), respectively. OTU04 and OTU05 were

134 detected in winter 2015, with the former being highly affiliated with the Tibetan cluster

135 (Xing et al. 2009; Huang et al. 2014). OTU05 was closely related to uncultured bacteria

136 detected in Feicui Reservoir and Green Lake. OTU06-08 were detected in summer

137 2016. OTU06 was closely related to Cyanobium JJM10D5. OTU07 was closely related

138 to the clade containing the Lake Biwa cluster and group E (Robertson et al. 2001),

139 which has been described as "Lake Biwa strains" (Crosbie et al. 2003). OTU08 was

140 highly affiliated with group H (Crosbie et al. 2003). 
141 The additional phylogenetic analysis based on the V3-V4 region (Fig. 3)

142 showed that OTU04 and OTU05 were related to LSI/LSII and PDII, respectively, all of

143 which were previously reported in Lake Superior (Ivanikova et al. 2007).

\section{Discussion}

145 No previous studies conducted in Lake Biwa have investigated seasonal variation of the

146 picocyanobacterial community at the genetic level, and their phylogenetic diversity

147 remains largely unknown. In the present study, by analyzing the partial 16S rRNA gene,

148 we found that picocyanobacteria in Lake Biwa were highly diverse and the community

149 structure varied by season (Fig. S1). The presence of OTU01 in both summers also

150 indicated that the same species may proliferate in the same time period regardless of

151 year. Unfortunately, due to the low abundance (i.e., no Synechococcus-related sequence

152 was detected in winter 2016; Fig. 1), it was unclear whether OTU04 or OTU05 was a

153 ubiquitous species in the winter season. One possible reason for the lack of a winter

154 bloom in 2016 was grazing pressure by cladocerans, since the individual density of

155 Daphnia spp. during the winter increased from 3.3 individuals $\mathrm{L}^{-1}$ in 2015 to 23.1

156 individuals $\mathrm{L}^{-1}$ in 2016 (Cai et al. 2020).

157 Most OTUs found in summer were closely related to clusters that have been

158 previously reported (Fig. 2). The relationship among OTU02 (Lake Biwa cluster),

159 OTU03 (group IV in Lake Suigetsu), and group E was especially robust, as confirmed

160 by the similar topology of phylogenetic trees in previous studies (Crosbie et al. 2003;

161 Ohki et al. 2012). By contrast, the group of OTU01 or OTU06 appeared to be a distinct

162 cluster that has not yet been described. The two groups may be lineages that adapt to 
163 meso-eutrophic conditions, since relative sequences were found in a variety of meso-

164 eutrophic lakes (Rajaniemi-Wacklin et al. 2008; Komárek et al. 2011; Cai and Kong

165 2013; Kojima et al. 2014). However, further studies are necessary to clarify their

166 ecological features.

167 Two OTUs were detected during the winter bloom, and the negative correlation

168 between abundance and temperature suggested that either or both of them may be

169 psychrotolerant species. Notably, OTU04 dominated the picocyanobacterial community

170 in winter (66.6\%, Fig. S1) and was highly affiliated with the Tibetan cluster (III-V in

171 Wu et al. 2010 and Huang et al. 2014; Fig. 2), which was ubiquitous and abundant in a

172 variety of cold, oligotrophic lakes on the Tibetan Plateau (Table 1). Most of these lakes

173 had low concentrations of total dissolved solids (TDS), except for Lake Nam Co, which

174 was oligosaline (Huang et al. 2014). The phylogenetic analysis based on the V3-V4

175 region (Fig .3) showed that OTU04 was also affiliated with the Lake Superior cluster

176 containing LSI and LSII, which have been reported as a distinct group endemic to Lake

177 Superior, an extremely oligotrophic lake with low water temperature and TDS content

178 (Table 1; Ivanikova et al. 2007; Callieri et al. 2013). Moreover, environmental

179 sequences identical to that of OTU04 have been frequently found in other water bodies,

180 such as Lake Baikal, high-altitude Pyrenean lakes, and waters in the Arctic region,

181 where temperature and trophic states are generally low. Therefore, it is likely that the

182 group of OTU04 is a psychrotolerant lineage distributed widely in oligotrophic water

183 systems with low-intermediate salinity.

184 Conversely, OTU05 was not related to any known clusters. Nevertheless, it has a

185 similarity greater than $97 \%$ with strains such as LBP1 (97.91\%); therefore, the group of 
186 OTU05 is probably a Synechococcus lineage. The closest relatives were found in the

187 epilimnion of Feicui Reservoir in December (Kojima et al. 2014) and near/under the

188 thermocline of Green Lake in September (Meyer et al. 2011; Fig. 2). The former is a

189 subtropical lake where the water temperature can reach as high as $20^{\circ} \mathrm{C}$ in winter, while

190 the latter is a saline meromictic lake with temperatures lower than $10^{\circ} \mathrm{C}$ near the

191 thermocline (Brunskill and Ludlam 1969). Unlike OTU04, the key determinant of the

192 distribution of this lineage remains unclear. Although both Feicui Reservoir (Chang and

193 Wen 1997) and Green Lake (Wisconsin Department of Natural Resources) are

194 mesotrophic, sequences of the V3-V4 region related to OTU05 have been detected in

195 both oligotrophic (e.g., Lake Superior) and eutrophic (e.g., Lake Waahi) lakes (Fig. 3).

196 Further studies are still needed to elucidate the characteristics of the group of OTU05;

197 studies on picocyanobacteria have been mostly conducted during warm seasons, when

198 they are abundant. Shedding more light on the winter communities will improve

199 understanding of the phylogeny and ecology of picocyanobacteria.

200 Acknowledgments. We are grateful to Drs. Yukiko Goda and Tetsushi Akatsuka and the crew

201 of our sampling vessel "HASU" for providing technical assistance during sample collection. We

202 also thank Dr. Yusuke Okazaki, Dr. Indranil Mukherjee, and Mr. Fujinaga Shohei for their

203 valuable help during sampling. This work was partly supported by KAKENHI, Grants-in-Aid

204 for Scientific Research, grant numbers 17K19289 and 19H03302 from the Japan Society for the

205 Promotion of Science, and the Environment Research and Technology Development Fund No.

206 5-1607 of the Ministry of the Environment. 


\section{References}

208

Altschul SF, Madden TL, Schäffer AA, Zhang J, Zhang Z, Miller W, Lipman DJ (1997) Gapped BLAST and PSI-BLAST: a new generation of protein database search programs. Nucleic Acids Res 25:3389-3402

Beardall J, Raven JA (2004) Potential effects of global change on microalgal photosynthesis, growth and ecology. Phycologia 43:26-40

Brunskill GJ, Ludlam SD (1969) Fayetteville Green Lake, New York. I. Physical and chemical limnology. Limnol Oceanogr 14:817-29

Cai Ji, Hodoki Y, Ushio M, Nakano S (2020) Influence of potential grazers on picocyanobacterial abundance in Lake Biwa revealed with empirical dynamic modeling. Inland Waters. doi: 10.1080/20442041.2020.1711682

Cai Y, Kong F (2013) Diversity and dynamics of picocyanobacteria and the bloomforming cyanobacteria in a large shallow eutrophic lake (Lake Chaohu, China). J Limnol 72:473-484

Callieri C (2008) Picophytoplankton in freshwater ecosystems: the importance of smallsized phototrophs. Freshw Rev 1:1-28

Callieri C, Coci M, Corno G, Modenutti B, Balseiro E, Bertoni R (2013) Phylogenetic diversity of nonmarine picocyanobacteria. FEMS Microbiol Ecol 85:293-301

Chapra SC, Dove A, Warren GJ (2012) Long-term trends of Great Lakes major ion chemistry. J Great Lakes Res 38:550-560

Choi DH, Noh JH, Shim J (2013) Seasonal changes in picocyanobacterial diversity as revealed by pyrosequencing in temperate waters of the East China Sea and the East Sea. Aquat Microb Ecol 71:75-90

Cottrell MT, Kirchman DL (2009) Photoheterotrophic microbes in the Arctic Ocean in summer and winter. Appl Environ Microbiol 75:4958-4966

Crosbie ND, Pöckl M, Weisse T (2003) Dispersal and phylogenetic diversity of nonmarine picocyanobacteria, inferred from 16S rRNA gene and cpcBA intergenic spacer sequence analyses. Appl Environ Microb 69:5716-5721

Dove A, Chapra SC (2015) Long-term trends of nutrients and trophic response variables for the Great Lakes. Limnol Oceanogr 60:696-721 
237 Dupont F, Chittibabu P, Fortin V, Rao YR, Lu Y (2012) Assessment of a NEMO-based 238 hydrodynamic modelling system for the Great Lakes. Water Qual. Res. J. Can., 47(3-4):198-214

Edgar RC (2018) Updating the 97\% identity threshold for 16S ribosomal RNA OTUs. Bioinformatics 34(14):2371-2375

Ernst A, Becker S, Wollenzien UI, Postius C (2003) Ecosystem-dependent adaptive radiations of picocyanobacteria inferred from $16 \mathrm{~S}$ rRNA and ITS-1 sequence analysis. Microbiology 149:217-228

Guildford S, Hecky RE (2000) Total nitrogen, total phosphorus, and nutrient limitation in lakes and oceans: Is there a common relationship? Limnol Oceanogr $45: 1213-1223$

Huang S, Liu Y, Hu A, Liu X, Chen F, Yao T, Jiao N (2014) Genetic diversity of picocyanobacteria in Tibetan lakes: assessing the endemic and universal distributions. Appl Environ Microbiol 80:7640-7650

Ivanikova NV, Popels LC, McKay RM, Bullerjahn GS (2007) Lake Superior supports novel clusters of cyanobacterial picoplankton. Appl Environ Microbiol 73:40554065

Jodłowska S, Śliwińska S (2014) Effects of light intensity and temperature on the photosynthetic irradiance response curves and chlorophyll fluorescence in three picocyanobacterial strains of Synechococcus. Photosynthetica 52:223-232

Kojima H, Tokizawa R, Kogure K, Kobayashi Y, Itoh M, Shiah FK, Okuda N, Fukui M (2014) Community structure of planktonic methane-oxidizing bacteria in a subtropical reservoir characterized by dominance of phylotype closely related to nitrite reducer. Sci Rep 4:5728

Komárek J, Kaštovský J, Jezberová J (2011) Phylogenetic and taxonomic delimitation of the cyanobacterial genera Aphanothece and Anathece. Eur J Phycol 46:315326

Kumar S, Stecher G, Li M, Knyaz C, Tamura K (2018) MEGA X: Molecular 
267 Lovejoy C, Vincent WF, Bonilla S, Roy S, Martineau MJ, Terrado R, Potvin M,

268

269

270

271

272

273

274

275

276

277

278

279

280

281

282

283

284

285

286

287

288

289

290

291

292

293

294

295

296

297

Massana R, Pedrós-Alió C (2007) Distribution, phylogeny, and growth of coldadapted picoprasinophytes in Arctic seas. J Phycol 43:78-89

Maeda H, Kawai A, Tilzer MM (1992) The water bloom of cyanobacterial picoplankton in Lake Biwa, Japan. Hydrobiologia 248:93-103

Meyer KM, Macalady JL, Fulton JM, Kump LR, Schaperdoth I, Freeman KH (2011) Carotenoid biomarkers as an imperfect reflection of the anoxygenic phototrophic community in meromictic Fayetteville Green Lake. Geobiology 9:321-329

Nagata T (1986) The seasonal abundance and vertical distribution of the $<3-\mu \mathrm{m}$ phytoplankton in the north basin of Lake Biwa. Ecol Res 1:207-221

Nakano S, Tanaka K, Sono T, Wakabayashi T, Ichise S, Yamanaka S, Kaneda E, Yada M, Naitoh M, Kawabe K, Maehata K, Fujiwara N, Maeda N, Nomura K, Nakanishi M (1996) Seasonal Changes in Horizontal Distribution of Algal Picoplankton in Lake Biwa with Special Reference to Water Temperature, Nutrient Levels and Heterotrophic Flagellates. Jpn J Limnol 57:49-55

Nübel U, Garcia-Pichel F, Muyzer G (1997) PCR primers to amplify 16S rRNA genes from cyanobacteria. Appl Environ Microbiol 63:3327-3332

Ohki K, Yamada K, Kamiya M, Yoshikawa S (2012) Morphological, phylogenetic and physiological studies of pico-cyanobacteria isolated from the halocline of a saline meromictic lake, Lake Suigetsu, Japan. Microbes Environ 27:171-178.

Price MN, Dehal PS, Arkin AP (2010) FastTree 2-approximately maximum-likelihood trees for large alignments. PLoS ONE 5(3):e9490

R Development Core Team (2018) R: A language and environment for statistical computing. R Foundation for Statistical Computing, Vienna, Austria. https://www.R-project.org/

Rajaniemi-Wacklin P, Rantala A, Kuuppo P, Haukka K, Sivonen K (2008) Cyanobacterial community composition in shallow, eutrophic Lake Tuusulanjärvi studied by microscopy, strain isolation, DGGE and cloning. Algol Stud 126:137-157

Robertson BR, Tezuka N \& Watanabe MM (2001) Phylogenetic analyses of Synechococcus strains (cyanobacteria) using sequences of the 16S rDNA and 
part of the phycocyanin operon reveal multiple evolutionary lines and reflect phycobilin content. Int J Syst Evol Micr 51: 861-871

Rognes T, Flouri T, Nichols B, Quince C, Mahé F (2016) VSEARCH: a versatile open source tool for metagenomics. PeerJ 4:e2584

Śliwińska-Wilczewska S, Maculewicz, Jakub \& Barreiro Felpeto, Aldo \& Latała, Adam (2018) Allelopathic and Bloom-Forming Picocyanobacteria in a Changing World. Toxins 10(1):48

Stockner JG, Antia NJ (1986) Algal picoplankton from marine and freshwater systems: a multidisciplinary perspective. Can J Aquat Sci 43:2472-2503

Stockner JG (1988) Phototrophic picoplankton: an overview from marine and freshwater ecosystems. Limnol Oceanogr 33:765-775

Stockner JG (1991) Autotrophic picoplankton in freshwater ecosystems: the view from the summit. Int Rev ges Hydrobiol 76:483-492

Stockner J, Callieri C, Cronberg G (2000) Picoplankton and other non-bloom-forming cyanobacteria in lakes. In: Whitton BA, Potts M (eds) The Ecology of Cyanobacteria. Dordrecht, Kluwer Academic Publishers, pp 195-231

Vörös L, Mózes A, Somogyi B (2009) A five-year study of autotrophic winter picoplankton in Lake Balaton, Hungary. Aquat Ecol 43:727-734

Wakabayashi T, Ichise S (2004) Seasonal variation of phototrophic picoplankton in Lake Biwa (1994-1998). Hydrobiologia 528:1-16

318 Weisse T (1993) Dynamics of autotrophic picoplankton in marine and freshwater ecosystems. Adv Microb Ecol 13:327-370

Wu QL, Xing P, Liu WT (2010) East Tibetan lakes harbour novel clusters of picocyanobacteria as inferred from the $16 \mathrm{~S}-23 \mathrm{~S}$ rRNA internal transcribed spacer sequences. Microb Ecol 59:614 - 622

Xing P, Hahn MW, Wu QL (2009) Low taxon richness of bacterioplankton in highaltitude lakes of the eastern Tibetan Plateau, with a predominance of Bacteroidetes and Synechococcus spp. Appl Environ Microbiol 75:7017-7025 
328 Yu G, Smith DK, Zhu H, Guan Y, Lam TTY (2017) ggtree: an R package for visualization and annotation of phylogenetic trees with their covariates and other associated data. Methods Ecol Evol 8:28-36 
331 Table 1. Comparison of environmental parameters in Lake Biwa (2015win), Tibetan

332 lakes, and Lake Superior.

333

\begin{tabular}{|c|c|c|c|c|c|c|c|c|}
\hline \multirow[b]{2}{*}{ Lake } & \multirow[b]{2}{*}{ Biwa $^{1}$} & \multicolumn{6}{|c|}{ Tibetan Plateau $^{2}$} & \multirow[b]{2}{*}{ Superior $^{3}$} \\
\hline & & Zhaling & E'ling & Tuosuhai & Xinxinhai & Nam Co & $\begin{array}{l}\text { Puma } \\
\text { Yumco }\end{array}$ & \\
\hline Sampling date & $\begin{array}{c}\text { Mar } \\
2016\end{array}$ & Jul 2005 & Jul 2005 & Jul 2005 & Jul 2005 & Jul 2004 & Oct 2008 & Sep 2004 \\
\hline Sampling depth (m) & 5 & $0-0.5$ & $0-0.5$ & $0-0.5$ & $0-0.5$ & $0-0.5$ & 0 & 5 \\
\hline Temperature $\left({ }^{\circ} \mathrm{C}\right)$ & 8.5 & 9.5 & 9.5 & 12.5 & 13 & 10.8 & 7.6 & 15 \\
\hline $\mathrm{pH}$ & 7.3 & 8.42 & 8.74 & 8.83 & 8.47 & 9.4 & 9.2 & 8 \\
\hline $\operatorname{TDS}\left(\mathrm{mg} \mathrm{L}^{-1}\right)$ & 48 & 616.4 & 428.2 & 566.3 & 673.2 & 1958 & 200 & 56 \\
\hline $\mathrm{T}-\mathrm{N}\left(\mathrm{mg} \mathrm{L}^{-1}\right)$ & 0.28 & 0.352 & 0.384 & 0.252 & 0.723 & 0.025 & & 0.396 \\
\hline $\mathrm{T}-\mathrm{P}\left(\mathrm{mg} \mathrm{L}^{-1}\right)$ & 0.011 & 0 & 0 & 0 & 0 & 0.025 & & 0.006 \\
\hline Trophic state & meso & oligo & oligo & oligo & oligo & oligo & oligo & oligo \\
\hline
\end{tabular}

1. Data were collected from Cai et al. 2020 and Japanese Ministry of Environmental Public Water database.

2. Data were cited from Xing et al. 2009 and Huang et al. 2014.

3. Data were collected from Guildford et al. 2000; Chapra et al. 2012; Dupont et al. 2012; and Dove and Chapra 2015.

T-N: total nitrogen; T-P: total phosphorus; Zero means below the detection limit. 
334 Figure 1. Seasonal dynamics of picocyanobacterial abundance (line with black dots) and 335 water temperature (gray area) in the epilimnion ( $5 \mathrm{~m}$ ) of Lake Biwa from July 2015 to 336 June 2017. The data were modified from Cai et al. 2020.

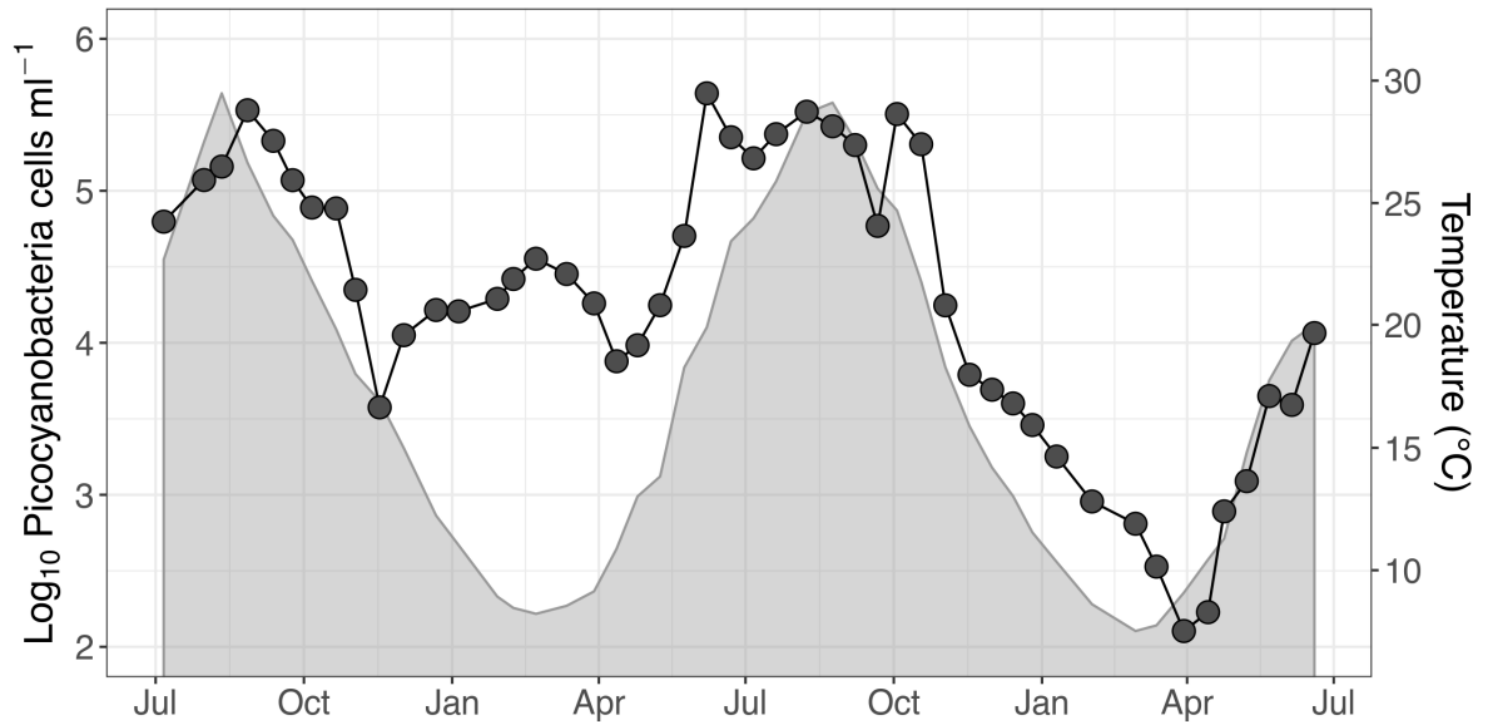


339 Figure 2. Maximum-likelihood tree inferred from 16S rRNA gene sequences (957 bp,

340 covering the highly variable regions V3-V8) of eight OTUs detected in Lake Biwa.

341 Bootstrap values are shown at nodes. The outgroup was Synechococcus elongatus

342 PCC6301.

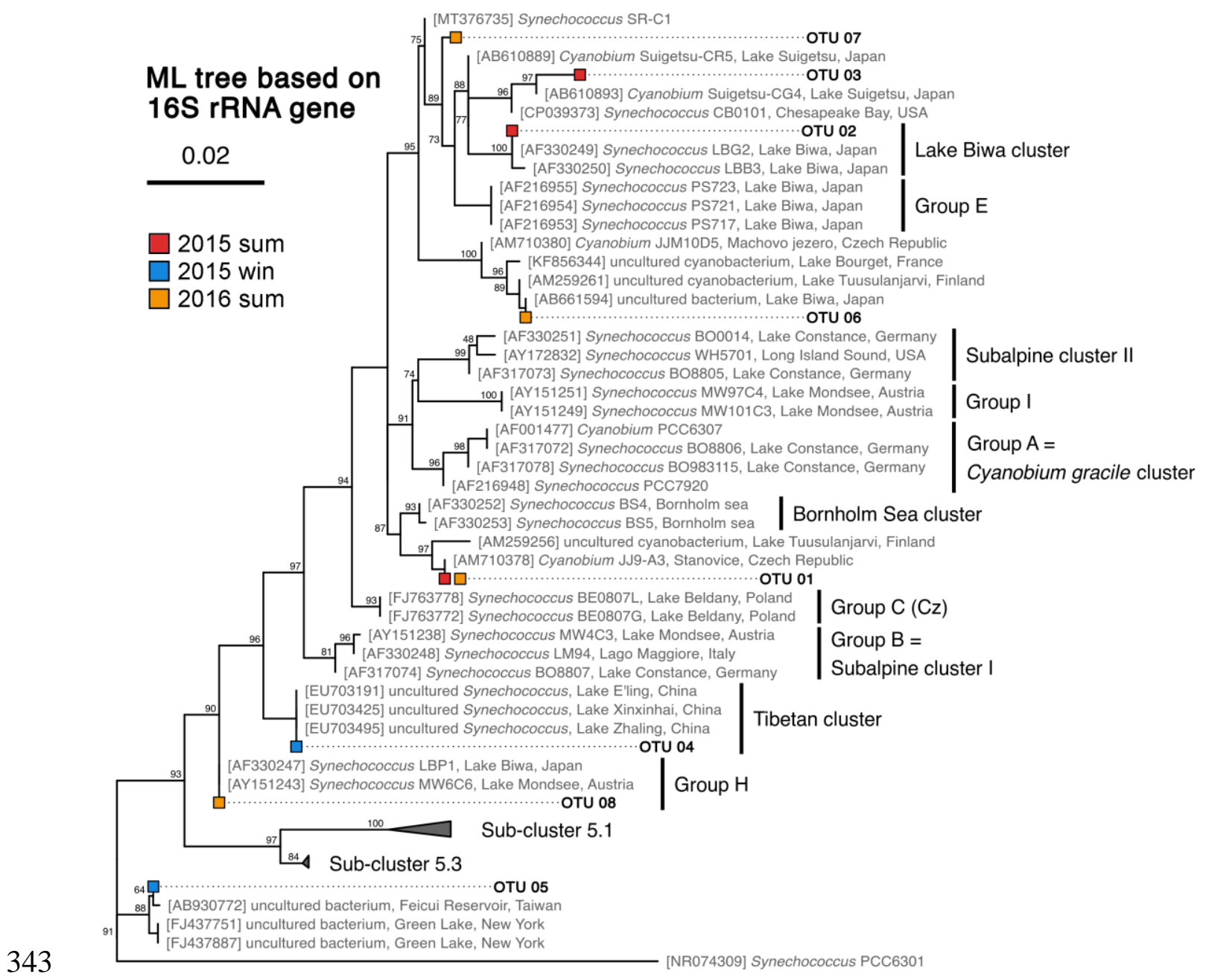


345 Figure 3. Maximum-likelihood tree based on the alignment of 16S rRNA gene

346 sequences (321 bp, covering the highly variable regions V3-V4) among OTU04,

347 OTU05, and highly similar environmental sequences, including several reference

348 clusters. Bootstrap values are shown at nodes.

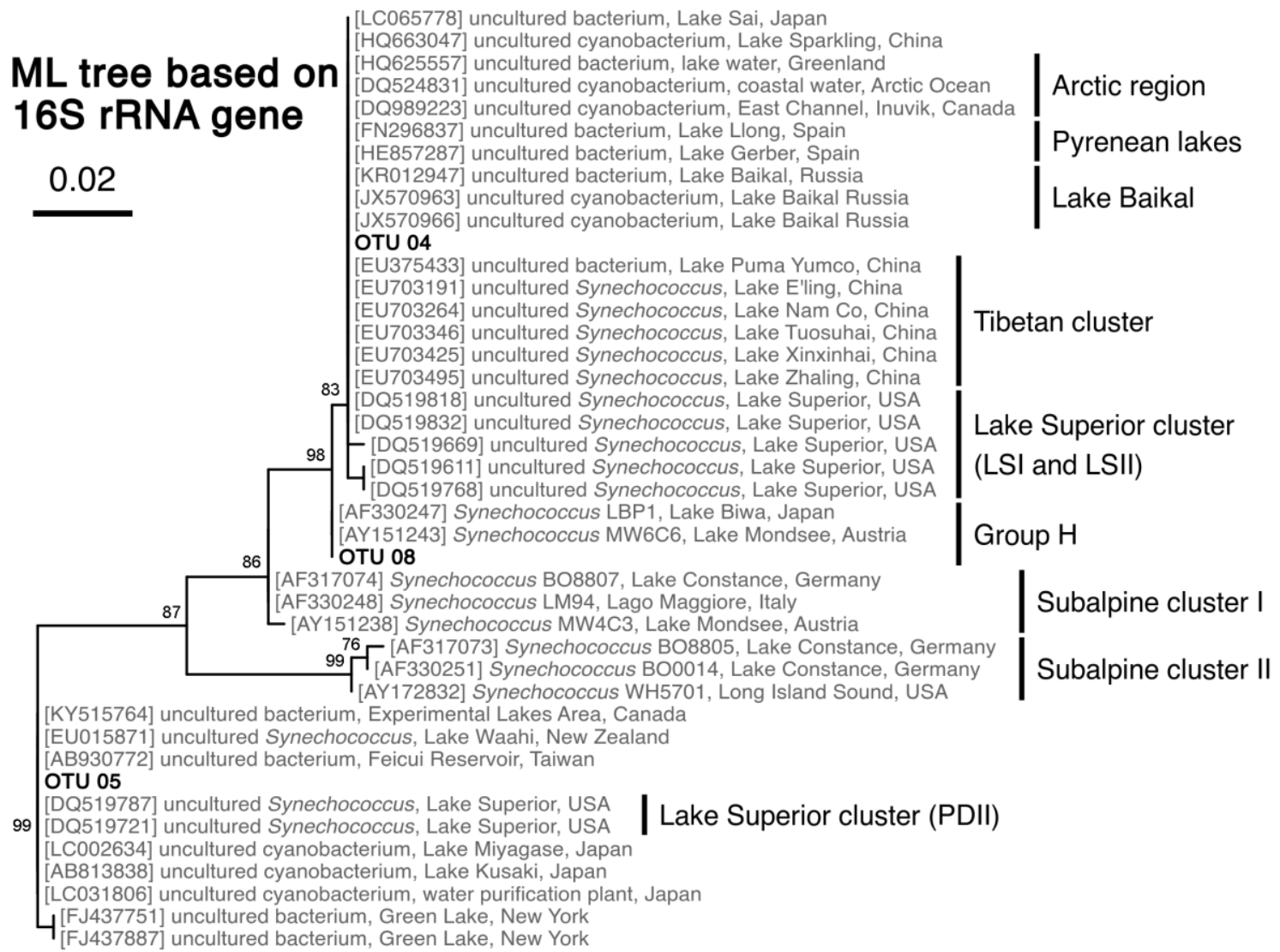


351 Figure S1. Percentage of read numbers for each OTU detected in Lake Biwa at different 352 seasons.

353
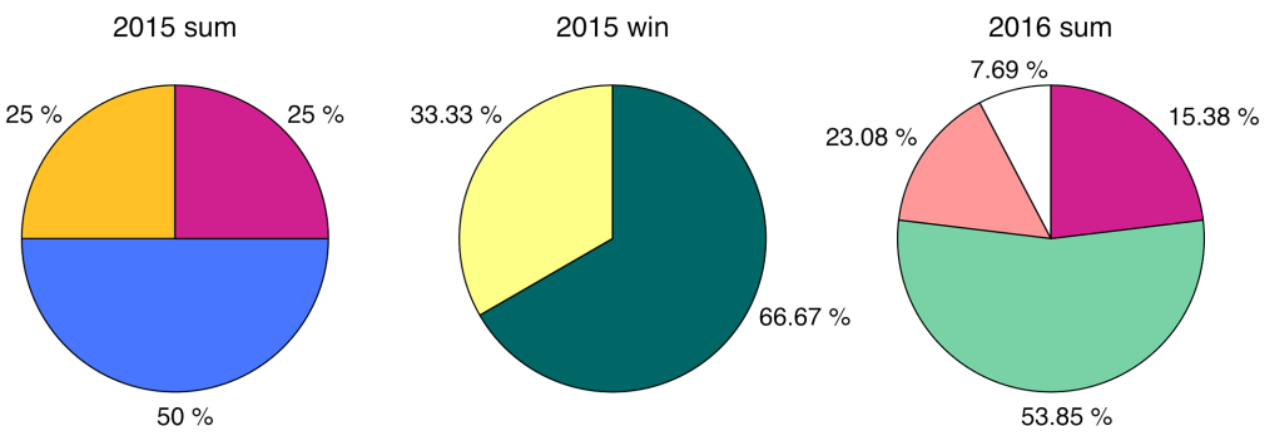

OTU01

OTU02

OTU03

OTU04

OTU05

OTU06

OTU07

OTU08

354

355

356 